\title{
Antimicrobial, antifungal effect and safety verification using BCOP assay of extracts from Coptis chinensis
}

\author{
Eun-Hee Kim ${ }^{1}$ (D) $\cdot$ Young-Ah Jang $^{1} \cdot$ Sol-Bi Kim ${ }^{1} \cdot$ Han-Hyuk Kim ${ }^{2} \cdot$ Jin-Tae Lee $^{1}$

\section{황련(Coptis chinensis) 추출물의 항균, 항진균 효과와 $\mathrm{BCOP}$ 분석을 이용한 안전성 검증}

\author{
김은희 ${ }^{1} \cdot$ 장영아 $^{1} \cdot$ 김솔비 $^{1} \cdot$ 김한혁 $^{2} \cdot$ 이진태 $^{1}$
}

Received: 26 June 2018 / Accepted: 18 September 2018 / Published Online: 30 September 2018

(C) The Korean Society for Applied Biological Chemistry 2018

\begin{abstract}
Coptis chinensis is used in oriental medicine for soothing, anti-inflammation, antimicrobial and antipyretic properties, and its main ingredient berberine is known to have strong antibacterial activity. In this study, we investigated the antimicrobial effect of hot water extract of Coptis chinensis (CW) on skin related microorganism and the airborne microbe, the antifungal effects of fungi, which are frequently detected in residential environments. $\mathrm{CW}$ showed antibacterial effect against Propionibacterium acnes, Staphylococcus aureus and Staphylococcus epidermidis, against the airborne microbe, which was collected in four different places. At the concentration of $100 \mathrm{mg} / \mathrm{mL}$, the antimicrobial activity continued for 42 days, showed heat stability without change in the antimicrobial activity even after heat treatment. The MIC and MBC of CW against $S$. aureus was 0.03 , $0.05 \mathrm{mg} / \mathrm{mL}$, against $S$. epidermidis was $0.50,0.75 \mathrm{mg} / \mathrm{mL}$ and against $P$. acne was $0.10,0.15 \mathrm{mg} / \mathrm{mL}$. As a result of measuring the MIC of four kinds of fungi with high detection frequency in
\end{abstract}

Jin-Tae Lee $(\bowtie)$

E-mail:kosmetics@hanmail.net

${ }^{1}$ Department of Cosmeceutical Science, Daegu Haany University, Gyeongbuk 38540, Republic of Korea

${ }^{2}$ Medical Convergence Textile Center, Reasearch \& Certification Team, Gyeongbuk Technopark, Gyeongbuk 38412, Republic of Korea

This is an Open Access article distributed under the terms of the Creative Commons Attribution Non-Commercial License (http://creativecommons org/licenses/by-nc/3.0/) which permits unrestricted non-commercial use, distribution, and reproduction in any medium, provided the original work is properly cited. the surrounding environment, Gliocladium virens was $65 \mathrm{mg} / \mathrm{mL}$ by determined as MIC which can inhibit one hundred percent of mycelial growth. The concentration $90 \mathrm{mg} / \mathrm{mL}$ was determined as MIC against Aureobasidium pullulans and $100 \mathrm{mg} / \mathrm{mL}$ against Penicilium pinophilum and Chaetomium globosum. CW was considered a safe extract that showed no irritation even in the ocular mucous membrane irritation evaluation test, a patch test. Therefore, these results suggest that Coptis chinensis has antimicrobial, antifungal and safety on human body and can be applied to the development of materials for cosmetic and residential environment industries.

Keywords Alternative methods - Antifungal - BCOP assay Human skin related microorganisms · Thermal stability

\section{서 론}

식물자원은 예로부터 생약원료로서 질병의 예방이나 치료에 이 용되어 왔다. 현대에 이르러 이러한 천연자원에 대한 이용개발 의 측면에서 과거 민간요법으로 사용했던 여러 가지 식물들 중 생리활성을 나타내며 식품의 기능 강화를 위해 주로 활용되고 있는 것으로 방향성 및 항산화 활성 관련 물질과 식품의 부패 와 변질을 유발하는 미생물에 대하여 항균활성을 나타내는 물 질들에 대한 연구가 활발하게 진행되고 있다[1-3]. 천연 항균제 의 보고인 식용식물의 항균활성 물질의 경우 alkaloid계, essential oil, flavonoid계, tannin을 비롯하여 대부분이 terpenoid 계와 quinone계, volatile oil 및 phenolic compound 등의 이차 
대사산물이거나 그 유도체들로 알려져 있다[4]. 방부제는 미생 물 증식을 방지하거나 지연시켜 제품의 변질 및 부패를 방지하 기 위하여 사용하는 성분으로. 식품, 화장품, 생활용품 등에서 사용되어진다. 소비자의 건강을 지향하는 성향과 함께 천연물에 대한 요구가 높아지고 있고, 합성 보존료가 첨가된 제품의 사 용을 기피하게 되면서[5], 산업계에도 인공 합성 보존제의 사용 을 제한하고 안전성이 확보된 천연 항균성 물질을 이용하고자 하는 연구가 집중되고 있다[6]. 항균력이 우수한 식물자원을 실 용화하기 위해서는 열에 대한 안정성이 확보되어야 하는데, 이 에 따른 연구로는 40 여종의 한약재를 검색한 결과 열 안정성에 서는 초두구와 소목 추출물이 안정성을 나타낸 것으로 보고하 였다[7]. 또한 감초 에탄올 추출물[8]과 와송의 부위별 추출물 [9]에서도 탁월한 항균 및 항진균 활성을 보였고, 열과 $\mathrm{pH}$ 에 대 해서도 비교적 안정성을 보여서 식품 천연 보존료로써 활용이 가능할 것으로 보고한 바 있다. 공기오염원인 미생물의 종류와 밀도는 사람 수, 사람의 활동 정도 및 통행에 따른 공기의 흐 름, 환기 등에 따라 달라지고, Airbone bacteria는 인체로부터 유래하며 이러한 미생물은 인체에도 악영향을 미칠 수 있다[10]. 기침, 재채기, 말하기와 같은 모든 인간의 행동은 공기의 이동 에 의해 운반되고 분산되어 지는 미생물 에어러졸을 생성한다. 이 입자들을 흡입하면 알레르기 반응을 일으킬 수 있지만, 감 염의 유무는 부분적으로 흡입된 미생물과 착상 지점에서 미생 물의 생존력 및 감염의 가능성에 달려있다[11]. 진균류 중 몇몇 곰팡이는 인체에 위험한 독성물질인 마이코톡신(myco-toxins)을 방출하는 것으로 알려져 있으며[12], 약 60여종 이상의 곰팡이 들이 알레르기성 비염과 천식을 초래하는 항원을 생산하는 것 으로 보고되고 있어 주거인의 건강을 크게 위협하고 있다[13]. 곰팡이는 주거환경뿐만 아니라 화장품 등 산업제품의 제조공정 중 제품에 유입되어 오염시키기도 한다. 1990년대 말부터 다양 한 건축물에서의 실내 공기 중 미생물 분포에 대한 연구가 진 행되었다. 최종태 등은 병원에서의 공기 중 미생물 분포에 대 해 조사하여 병원의 각 구역별 농도분포와 가장 높은 빈도로 검출된 진균에 대해 보고하였고[14], 정윤희 등은 건물 내 환기 와 세균 및 진균의 농도관계에 대해 조사 및 보고하였다[15]. Aureobasidium pullulans는 토양, 목재 및 집안 먼지와 같은 환 경에 널리 분포되어 있으며[16], 가습기나 에어컨을 통해 A.pullulans에 만성적으로 노출되면 과민성 폐렴이나 “가습기 폐" 로 이어질 수 있다[17]. Gliocladium virens는 Hypocreaceae의 자엽 곰팡이이며, 인간에 대한 원인균은 Gliocladium과 같은 mitosporic이다[18]. Penicillium pinophilum은 파푸아 뉴기니의 라디오에서 분리된 Penicillium속의 종으로 3-O-methylfunicone 과 mycophenolic acid를 생산한다[19]. Chaetomium globosum 은 주로 식물, 토양, 짚 및 배설물에 서식하며, 인간의 알러지 항원, 조직변성 및 신경계 감염의 기회감염성 물질로 작용한다 [20]. Aspergillus niger는 Aspergillus속의 가장 일반적인 종 중 하나이며, 포도, 살구, 양파, 땅콩과 같은 특정 과일과 채소에 검은 곰팡이라는 질병을 일으키는 음식의 흔한 오염 물질이다 [21]. 황련은 미나리아재비과의 여러해살이 초본식물로 중국이 원산이며, 생약용으로 한국, 일본, 중국 등지에서 재배하기도 한 다. 한방에서는 11월경에 5-6년 된 황련, 일황련의 뿌리를 채취 하여 햇볕에 말린 것을 황련이라 하며, 특이한 냄새를 가지고, 그 맛은 쓰며, 성질은 차다[22]. 성분은 isoquinoline계 alkaloid
인 berberin, jateorrhizine, palmatine, coptisine, magnoflorine, epiberberin, berbestine, worenine 및 ferulic acid 등 함유하며, 주성분인 berberin은 용혈성 연쇄구균, 흥막염균, 폐렴상구균, 콜 레라균, 탄저균 및 황색포도상구균에 대한 강한 억제효과를 나 타낸다[23]. 많은 피부질환이 피부상재균에 의해 발생되며 이 중 Propionibacterium acne, Staphyiococcus aureus, Staphyiococcus epidermidis, Escherichia coli, Pseudomonas aeruginosa는 여드 름 및 아토피 등 대표적인 피부질환과 관련된 균주이다. 피부 상재균 이외에도 화장품을 변질시키는 세균도 피부에 악영향을 주고 있으며, 주거공간 내의 곰팡이 발생은 질병을 유발한다. 이를 사멸하기 위해 다양한 종류의 항균제나 방부제를 필수적 으로 사용하고 있는데 기존에 사용되고 있는 합성물질들은 인 체에 알레르기를 유발하기도 한다. 따라서 인체에 안전하면서도 항균성, 방부력을 가진 천연 소재에 관한 연구가 필요한 시점 이다.

이전의 연구에서 황련의 항균 효과는 충분히 진행되었으나, 주거환경에 존재하는 곰팡이에 대한 항진균 활성 검증은 미비 하였다. 본 연구에서는 황련의 항균성, 항진균성에 대해 조사하 고, 화장품 및 주거 환경을 안전하게 유지하는 기능을 가진 천 연 소재의 가능성을 검증하고자 하였다

\section{재료 및 방법}

\section{식물재료}

본 실험에서 사용한 황련은 2017년 대구 약령시 한남약업사로 부터 건조된 시료를 구입하였으며, 깨끗이 세척하여 그늘에서 3 일 동안 건조시킨 후 $4{ }^{\circ} \mathrm{C}$ 에서 보관하였다.

\section{시료추출}

건조 된 황련 $(500 \mathrm{~g})$ 과 물을 $1: 9$ 로 하여 $85^{\circ} \mathrm{C}$ 에서 3 시간 동안 3 회 반복하여 환류추출 한 다음 filter paper (Whatman No. 2, GE, Tokyo, Japan)를 사용하여 여과하였다. Vacuum Rotary Evaporator (N-3010, EYELA, Tokyo, Japan)로 추출물을 감압 농축한 다음, 96시간동안 동결건조기(MCFD8508, IlShinBioBase, Dongducheon, Korea)로 건조하여 황련 열수추출 분말(102.3 g) 을 얻었고, 수율은 $20.46 \%$ 였다. 본 실험에서 황련 열수 추출물 $(\mathrm{CW})$ 의 농도 조절은 D. I water로 하여 수행하였다.

\section{사용균주}

항균력을 평가하기 위해 3종의 그람양성균[Staphyiococcus aureus (KCTC 1621), Staphyiococcus epidermidis (KCTC 1917), Propionibacterium acne (KCTC 3314)]과 2종의 그람음성균 [Escherichia coli (KCTC 1039), Pseudomonas aeruginosa (KCTC 2513)]의 피부상재균 5 종을 사용하였고, 항진균력을 평 가하기 위해 생활환경에 분포하는 5종의 진균[Aspergillus niger (ATCC 9642), Penicilium pinophilum (ATCC 11797), Chaetomium globosum (ATCC 6205), Aureobasidium pullulans (ATCC 15233), Gliocladium virens (ATCC 9645)]을 사용하였다. 본 연구에 사 용된 균주는 한국생물자원센터 (KCTC, Jeongeup, Korea)와 American Type Culture Collection (ATCC, Manassas, VA, $\mathrm{USA}$ )에서 분양 받아 실험하였다. 


\section{Disc diffusion method에 의한 항균활성 측정}

시료의 항균활성은 디스크 확산법(disc diffusion method)에 의 해 측정되었다[24,25]. 각 균주의 colony 1 개를 취해 각각의 액 체배지에 접종하여 24-36시간 동안 활성화 시킨 후 3회 계대배 양 하였다. 시험균은 $660 \mathrm{~nm}$ 에서 optical density (O.D)값이 0.8 이 되게 배양한 후 $1 \times 10^{6} \mathrm{CFU} / \mathrm{mL}$ 의 농도로 현탁하여 agar배 지에 도말하고, $8 \mathrm{~mm}$ paper disc를 고정시켰다. 시료의 농도는 $10,50,100 \mathrm{mg} / \mathrm{disc}$ 또는 $5,10,50 \mathrm{mg} / \mathrm{disc}$ 가 되게 하여 디스 크에 완전히 흡수시킨 후 $37^{\circ} \mathrm{C}$ incubator에서 24시간 배양시켜 항균활성에 의해 형성된 생육저해환(clear zone)을 측정하여 평 가하였다.

\section{최소저해농도(Minimum Inhibitory Concentration, MIC)와 최소사멸농도(Minimum Bactericidal Concentration, MBC) 측정}

시료의 항균활성을 확인하기 위해 최소저해농도(MIC)와 최소사 멸농도(MBC)를 측정하였다[26]. 시료는 각각의 액체배지에 희 석하였고, 시험균의 농도는 $1 \times 10^{4} \mathrm{CFU} / \mathrm{mL}$ 의 농도로 현탁하여 측정하였다. 시험균이 접종된 $500 \mu \mathrm{L}$ 의 액체배지와 $500 \mu \mathrm{L}$ 의 샘플을 $24 \mathrm{well}$ plate에 첨가한 후 연속적으로 2 배 희석(broth microdilution method)하여 농도의 범위를 정하였다. $37^{\circ} \mathrm{C}$ 에서 24 시간 배양 후 배양액의 탁도를 판단하고 agar배지에 도말하 여, 24시간 배양 후 시험균의 저해가 보여지는 최소농도를 MIC 로 결정하였으며[27], agar배지에 도말하여 24시간 배양 후 시 험균의 생장이 보이지 않는 최소농도를 $\mathrm{MBC}$ 로 결정하였다.

\section{열 안정성 검정}

동결 건조한 $\mathrm{CW}$ 를 분말상태로 $70,90,110,130,150$ 및 180 ${ }^{\circ} \mathrm{C}$ 에서 5 분간 열처리한 후 각각 $100 \mathrm{mg} / \mathrm{disc}$ 농도로 무처리군 과 Staphyiococcus aureus에 대한 항균활성의 변화를 측정하여 비교하였다.

\section{항진균 활성 측정}

항진균 활성은 ASTM G-21법[28]과 한천 확산법[29]을 변형하 여 측정하였다. ASTM G-21법은 생활환경에 존재하는 곰팡이 의 생장에 대한 시료의 저항성을 테스트하는데 매우 일반적으 로 사용되어진다. 곰팡이의 플러그를 agar 배지 위에 밀착시킨 후 플러그의 상단에 $6 \mathrm{~mm}$ paper disc를 고정시켰다. 시료의 농 도는 $10,50,100 \mathrm{mg} / \mathrm{mL}$ 이 되게 하여 paper disc에 완전히 흡 수시킨 후 $25^{\circ} \mathrm{C}$ incubator에서 3-14일 동안 배양하였다. 대조 군으로 D. I water와 현재 합성보존제로 사용되고 있는 Hydroxyacetophenone 성분을 주원료로 하는 Bluechem사의 Hydmol-HDE (Bluechem inc., Ansung, Korea)를 사용하였다. 시료의 항곰팡이 저항성은 Table 1에 나타낸 agar 배지 표면의 곰팡이 생장의 면적 비율을 Mold Index를 이용하여 평가하였다.

\section{Patch test를 이용한 피부자극 측정}

시료의 피부자극을 평가하기 위해 Cosmetic, Toiletry \& Fragrance Association (CTFA) [30]의 안전성 테스트 가이드라 인에 따라 패치 테스트를 실시하였다. 피부병이나 알러지가 없 는 36명의 피실험자가 실험에 참여 하였다. Scanpor tape에 부 착된 finn chamber (FINN CHAMBER 8MM, Epitest Ltd
Table 1 Mold Index by ASTM G-21

\begin{tabular}{lc}
\hline \multicolumn{1}{c}{ Observed mold growth } & Mold Index \\
\hline No Growth & 0 \\
Trace of Growth (less than 10\% coverage) & 1 \\
Light Growth (10-30\% coverage) & 2 \\
Medium Growth (30-60\% coverage) & 3 \\
Heavy Growth (60-100\% coverage) & 4 \\
\hline
\end{tabular}

Table 2 IVIS (In Vitro Irritation Score) and classification used in BCOP assay

\begin{tabular}{cl}
\hline \hline IVIS & \multicolumn{1}{c}{ UN GHS* } \\
\hline $\mathrm{S} 3$ & Not classified \\
$\mathrm{S}>3, \leq 55$ & No prediction can be made \\
$\mathrm{S}>55$ & Category1 \\
\hline
\end{tabular}

*UN GHS: United Nations Globally Harmonized System

Oy, Helsinki, Finland)를 팔안쪽의 적절한 부위에 부착하여 밀 폐하였고, 24시간 후에 패치를 제거하고, ICDRG (International Contact Dermatitis Research Group)의 기준에 따라 패치 제거 후 30 분 및 24 시간에 시험 영역의 자극에 대해 평가 하였다.

\section{동물대체시험법을 이용한 안자극 측정}

Bovine corneal opacity and permeability (BCOP) test는 Draize rabbit eye test의 동물대체시험법으로 적용되었다[31]. $\mathrm{BCOP}$ 분석은 이전에 보고된 방법을 수정하여 적용하였다[32]. 경산지역의 도축장에서 당일 도축하여 적출한 소의 안구를 멸 균하여 $100 \mathrm{IU} / \mathrm{mL}$ 의 penicillin과 $100 \mu \mathrm{g} / \mathrm{mL}$ 의 streptomycin을 첨가한 4의 Hank's Balanced Salt Solution $\left(\mathrm{GIBCO}^{\circledR} \mathrm{HBSS}\right.$, Thermo Fisher Scientific Inc, Waltham, MA, USA)에 보존하 여 실험실로 운반하였다. 각막은 가장자리의 $2 \sim 3 \mathrm{~mm}$ 의 공막을 포함하여 분리 후 각막홀더에 고정시켰다. 챔버의 상하단에 phenol red를 불포함 하는 $\mathrm{MEM}$ 배지 $\left(\mathrm{GIBCO}^{\circledR} \mathrm{MEM}(1 \mathrm{X})\right.$, Thermo Fisher Scientific Inc, Waltham, MA USA)를 채우고, 1 시간 동안 $32{ }^{\circ} \mathrm{C}$ 에서 배양 후 상 - 하단 모두 새로운 phenol red 불포함 MEM배지로 교환하고, Opacitometer (Opacitometer OP3.0, DURATEC, Hockenheim, Germany)를 사용하여 혼탁도 를 측정하였다. 챔버 상단의 배지를 제거 후 시험물질(액상) 750 $\mu \mathrm{L}$ 를 10 분간 도포하였다. 시험물질 처리 후, phenol red를 함유 한 $\mathrm{MEM}$ 배지로 3 회 세척하고, 챔버 상단에 새로운 $\mathrm{MEM}$ 배지 를 채워 2 시간 동안 $32{ }^{\circ} \mathrm{C}$ 에서 추가배양 하였다. Opacitometer 로 혼탁도를 측정한 후 양쪽 챔버의 배지를 제거하고, 하단에 새로운 MEM 채우고, 전방 챔버에는 fluorescein solution을 1 $\mathrm{mL}$ 주입하였다. $32{ }^{\circ} \mathrm{C}$ 에서 90 분 동안 배양하고, 챔버 하단의 MEM 배지를 모두 수거하여, 96well plate에 시료당 3개 well 에 $360 \mu \mathrm{L}$ 씩 분주한 후 $492 \mathrm{~nm}$ 에서의 흡광도를 측정하였다. 안 점막자극지수(In Vitro Irritancy Score, IVIS) 산출식은 다음과 같다.

IVIS $=$ Opacity average $(15 \times$ Permeability average $)$

계산된 IVIS를 Table 2와 같이 Globally Harmonized System (GHS) 기준으로 하여 자극을 분류하였다. 
Table 3 Antimicrobial activity of variety plant extracts against Staphylococcus aureus

\begin{tabular}{|c|c|c|c|}
\hline Sample & S. aureus & Sample & S. aureus \\
\hline Coptis chinensis $(\mathrm{W})^{\mathrm{a}}$ & +++ & Pinus rigida $(\mathrm{E})$ & - \\
\hline Rhus chinensis (W) & +++ & $\begin{array}{l}\text { Vaccinium corymbosum leaf } \\
\text {-harvest in summer }(\mathrm{E})\end{array}$ & - \\
\hline $\begin{array}{l}\text { Vaccinium corymbosum leaf } \\
\text {-harvest in November (W) }\end{array}$ & ++ & $\begin{array}{l}\text { Vaccinium corymbosum leaf } \\
\text {-harvest in summer (W) }\end{array}$ & - \\
\hline Rhus chinensis $(\mathrm{E})^{\mathrm{b}}$ & ++ & Chrysanthemum indicum L. (W) & - \\
\hline Reynoutria elliptica (W) & ++ & Phellinus linteus $(\mathrm{E})$ & - \\
\hline Reynoutria elliptica (E) & ++ & Phellinus linteus (W) & - \\
\hline $\begin{array}{l}\text { Vaccinium corymbosum leaf } \\
\text {-harvest in November }(\mathrm{E})\end{array}$ & + & Phellinus linteus $(\mathrm{M})^{\mathrm{d}}$ & - \\
\hline Hydrangea serrata Seringe (W) & + & Phellinus linteus $(\mathrm{C})^{\mathrm{e}}$ & - \\
\hline Dendropanax morbifera $(\mathrm{E})$ & - & Curcuma longa $(\mathrm{W})$ & - \\
\hline Chestnut inner shell (W) & - & Houttuynia cordata (W) & - \\
\hline Chestnut inner shell (E) & - & Melaleuca alternifolia $(\mathrm{W})$ & - \\
\hline Chestnut inner shell $(\mathrm{A})^{\mathrm{c}}$ & - & Hydrangea serrata Seringe (E) & - \\
\hline Pinus rigida $(\mathrm{W})$ & - & & \\
\hline
\end{tabular}

+ is inhibition effect on antimicrobial, - is no inhibition effect on antimicrobial.

a: water extract, b: 70\% ethanol extract, c: acetone extract, d: methanol extract, e: chloroform layer, -: no inhibition

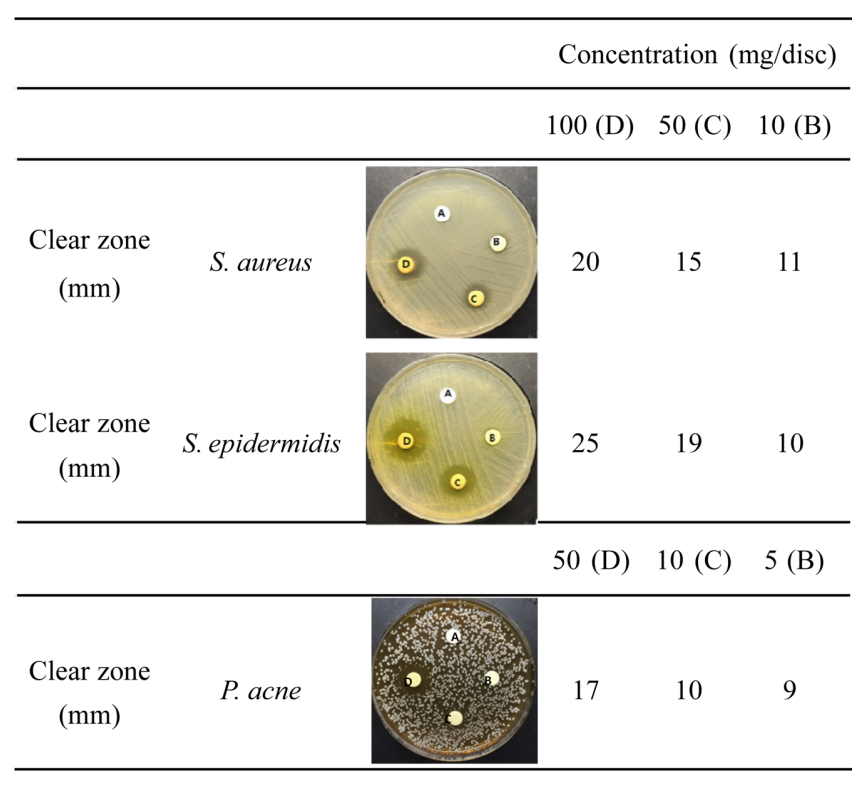

Fig. 1 Antimicrobial activities of CW against three strains. The inoculum (about $1 \times 10^{6}$ ) was spread on the different media then, were grown at 37 ${ }^{\circ} \mathrm{C}$ for $24 \mathrm{~h}$. The antimicrobial activity was evaluated by measuring the zone $(\mathrm{mm})$ of inhibition against the test microorganisms

\section{통계처리}

결과 통계처리는 SPSS 10.0 을 사용하였으며, 유의차 검증은 분 산분석(ANOVA: analysis of variance)프로그램을 이용하여 ttest를 이용하여 통계적 유의수준 $p<0.05,0.01$ 에서 검증하였다.

\section{결 과}

Staphylococcus aureus에 대한 다양한 식물 추출물의 항균 활성 S. aureus (KTCT 1621)에 대하여 $\mathrm{CW}$ 와 이전 문헌에 항균효과

\begin{tabular}{|c|c|c|c|c|}
\hline & & \multicolumn{3}{|c|}{ Concentration $(\mathrm{mg} /$ disc $)$} \\
\hline & case & 100 & 50 & 10 \\
\hline \multirow{4}{*}{$\begin{array}{l}\text { Clear } \\
\text { zone } \\
(\mathrm{mm})\end{array}$} & case 1 & 20 & 17 & 9 \\
\hline & case 2 & 18 & 13 & 8 \\
\hline & case 3 & 18 & 11 & 8 \\
\hline & case 4 & 19 & 15 & 9 \\
\hline
\end{tabular}

Fig. 2 Antimicrobial activity of CW against airborne microbes. TSA was stand for $20 \mathrm{~min}$ at each livingroom of four different houses. The airborne microbe-collected petri dishes were incubated at $32{ }^{\circ} \mathrm{C}$ for 48 hours then antimicrobial activity of $\mathrm{CW}$ was evaluated by paper disc diffusion method

가 있는 것으로 보고된[33-44] 12종 식물에서 25개 추출물 샘 플과 같은 농도 $(10,50,100 \mathrm{mg} / \mathrm{disc})$ 조건에서 항균 활성 실험 을 진행하여 그 결과를 비교 하였다. $\mathrm{CW}$ 는 가장 높은 항균 활 성을 나타내었다(Table 3). 이숙지의 보고에 따르면[45] 황련 열 수 추출물은 에탄올 추출물보다 우수한 항균 효과를 나타내었 다. 따라서, 본 실험도 황련 열수 추출물 $(\mathrm{CW})$ 로 수행하였다.

\section{황련 열수 추출물의 항균 효과}

본 연구에서는 여드름의 가장 중요한 원인균인 P. acne와 염증 을 악화시키는 S. aureus, S. epidermidis, E. coli 및 P. aeruginosa 


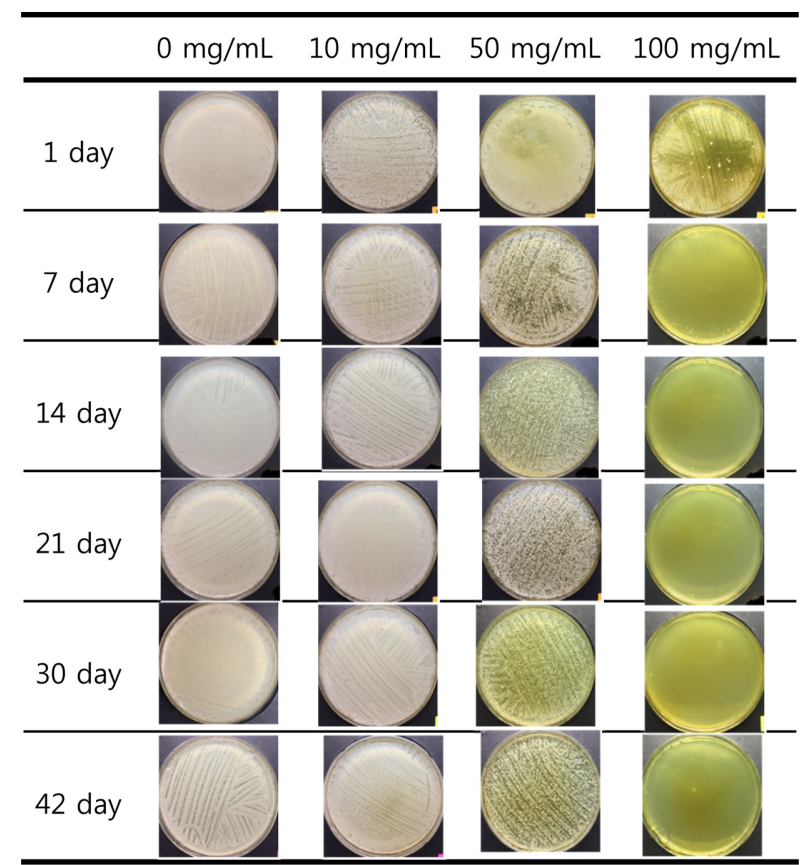

Fig. 3 Antimicrobial sustainability test of $\mathrm{CW}$. CW was added to the culture medium of Staphylococcus aureus at concentrations of $0,1,5$ and $10 \mathrm{mg} / \mathrm{mL}$, then on $1,7,14,21,30$, and 42 days the culture broth was tested to the agar medium to analyze the antimicrobial activity and sustainability

의 피부상재균 5 종에 대한 $\mathrm{CW}$ 의 항균 활성을 측정하였다. 피 부병의 대부분은 피부 박테리아에 의해 유발되며, P. acnes, $S$. aureus, S. epidermidis, E. coli 및 P. aeruginosa는 여드름 및 아토피와 같은 전형적인 피부 질환과 관련이 있다. $\mathrm{CW}$ 의 항균 활성을 측정하기 위해 디스크 확산법이 수행되었고, paper disc 주위의 억제 영역은 항균 활성으로 평가되었으며, 더 큰 생육 저해환(clear zone)의 직경은 더 높은 항균 활성으로 평가되었 다[46]. S. aureus, S. epidermidis에 대해서는 $10,50,100 \mathrm{mg}$ $\mathrm{disc}$ 의 농도로 $P . a c n e$ 에 대해서는 $5,10,50 \mathrm{mg} / \mathrm{disc}$ 의 농도로 항균 활성 측정 결과 농도의존적으로 생육저해환의 직경이 증 가하였다(Fig. 1). $\mathrm{CW}$ 는 3종의 균주(그람양성균)에 대한 항균 활성은 나타내었으나, 그람음성균인 E. coli 및 P. aeruginosa에 대해서는 항균 효과를 나타내지 않았다(data not shown).

\section{주거환경에 대한 황련 열수 추출물의 항균 효과 측정}

공기 중 미생물은 기침, 재채기, 말하기 등과 같은 공기의 이동 에 의해 운반되고 분산되어 미생물 에어로졸을 발생시킨다 $[47,48]$. 공기 중 미생물에 대한 $\mathrm{CW}$ 의 항균 활성을 측정하기 위해 각기 다른 네 곳의 가정집 거실에 $\mathrm{TSA}$ 배지를 20 분 동안 개방하여 낙하균을 포집하였다. 각각의 낙하균이 포집된 TSA 배지를 $32{ }^{\circ} \mathrm{C}$ 에서 48 시간 동안 배양한 후 $\mathrm{CW}$ 의 항균 활성을 평가하였다(Fig. 2). $\mathrm{CW}$ 는 공기 중 미생물에 대해 농도의존적 으로 항균 활성을 보였으며, 이 경우 미생물에 대한 그람염색 은 모두 그람양성균임을 나타내었다.

$\mathrm{CW}$ 의 항균 활성 지속성을 분석하기 위해 $0,10,50$ 및 100
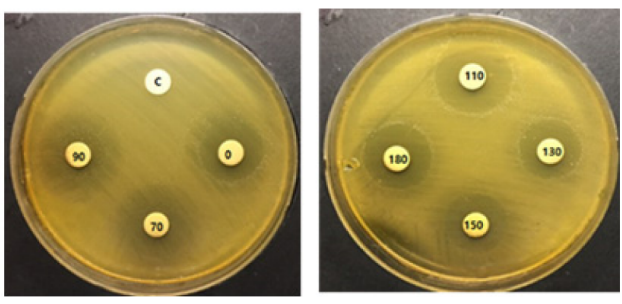

Fig. 4 Determination of thermal stabilitty of $\mathrm{CW}$. CW was heat treate at $70,90,110,130,150$ and $180{ }^{\circ} \mathrm{C}$ for $5 \mathrm{~min}$ and then they were tested to antimicrobial activity against Staphylococcus aureus by paper disc diffusion method. c: control (D.I water), 0: no treatment, 70, 90, 110, 130, 150, 180: heating temperature

Table $4 \mathrm{MIC}$ and $\mathrm{MBC}$ of $\mathrm{CW}$ against three microorganisms

\begin{tabular}{cccc}
\hline \hline & S. aureus & S. epidermidis & P. acne \\
\hline MIC $(\mathrm{mg} / \mathrm{mL})$ & 0.03 & 0.05 & 0.10 \\
MBC $(\mathrm{mg} / \mathrm{mL})$ & 0.05 & 0.75 & 0.15 \\
\hline
\end{tabular}

$\mathrm{mg} / \mathrm{mL}$ 의 농도로 $S$. aureus를 배양한 액체배지에 첨가 후, 1 , $7,14,21,30$ 및 42일에 배양액을 TSA배지에 도말하였다. 그 결과, $\mathrm{CW}$ 를 함유하지 않은 배양액과 $10 \mathrm{mg} / \mathrm{mL}$ 농도의 배양액 은 항균활성을 나타내지 않았으며, $50 \mathrm{mg} / \mathrm{mL}$ 농도의 배양액은 $10 \mathrm{mg} / \mathrm{mL}$ 농도의 배양액보다는 높은 항균 활성과 지속성을 보 였다. $100 \mathrm{mg} / \mathrm{mL}$ 농도에서 1 일 후까지는 항균 활성이 관찰되 지 않았으나, 7일 후 강한 항균 활성과 실험이 끝나는 시점인 42일까지도 지속성이 관찰되었다(Fig. 3).

\section{황련 열수 추출물의 열 안정성}

가공품의 대부분은 유해생물을 효과적으로 제어하기 위해 열처 리과정을 거치게 된다. 따라서, 가공품에 첨가될 성분의 활성은 가공 공정 중에 유지되어야 한다. $\mathrm{CW}$ 의 열 안정성을 측정하기 위해 $\mathrm{CW}$ 를 $70,90,110,130,150,180^{\circ} \mathrm{C}$ 에서 5 분간 열처리 한 후 S. aureus에 대한 항균활성을 평가하였다. $\mathrm{CW}$ 의 항균 활 성은 모든 조건에서 유지되었다(Fig. 4). 이 결과는 Schizandra chinensis, Orostachys japonicus와 Sargassum thunbergii 추출 물이 열처리 후에도 항균 활성의 변화가 없었던 결과와 일치 한다[48-50]. 이는 $\mathrm{CW}$ 는 가공 과정 중 열처리가 수반되어지는 가공품에 항균 활성을 유지하는 첨가물로 사용 가능함을 보여 준다.

\section{최소저해농도(MIC)와 최소사멸농도 $\mathrm{MBC)}$ 측정}

$\mathrm{CW}$ 의 농도별 broth microdilution method를 시행하여 3종의 균 주에 대한 $\mathrm{MIC}$ 와 $\mathrm{MBC}$ 를 측정한 결과는 Table 4와 같다. $S$.

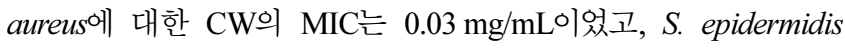
는 $0.50 \mathrm{mg} / \mathrm{mL}, P$. acne는 $0.10 \mathrm{mg} / \mathrm{mL}$ 였다. $S$. aureus 에 대한 $\mathrm{MBC}$ 의 수치는 $0.05 \mathrm{mg} / \mathrm{mL}$ 이었고 $S$. epidermidis는 $0.75 \mathrm{mg}$ / $\mathrm{mL}, P$. acne는 $0.15 \mathrm{mg} / \mathrm{mL}$ 이었다. $\mathrm{CW}$ 는 그람양성균 중에서 $S$. aureus에 대해 가장 강한 항균 활성을 보였다. 9종의 한약재 중 가장 항균 활성이 뛰어난 오배자(Rhus javanica Linne) 추출 물의 S. aureus에 대한 $\mathrm{MIC}$ 와 $\mathrm{MBC}$ 가 각각 $2.4,4.7 \mathrm{mg} / \mathrm{mL}$ 인 것과 비교하여 더 우수한 항균활성을 가진다고 보여진다[51]. 


\begin{tabular}{|c|c|c|c|c|c|}
\hline & A.pullulans & G.virens & P.pinophilum & C.globosum & A.niger \\
\hline M.I. & 4 & 4 & 4 & 4 & 4 \\
\hline control & & & & & \\
\hline M.I. & 0 & 0 & 0 & 0 & 4 \\
\hline $\mathrm{CW}$ & & & & & \\
\hline
\end{tabular}

Fig. 5 Antifungal performance of $\mathrm{CW}$ on fungi. The plugs of fungus were placed on agar plate. The paper disc $(0.6 \mathrm{~cm}$ diameter $) \mathrm{containing} \mathrm{CW}$ was placed on the top of each plug. After incubation for 3-14 days, the antifungal effect of $\mathrm{CW}$ was evaluated by using Mold Index of fungus growth area ratio on the surface of agar. concentration of $\mathrm{CW}: 100 \mathrm{mg} / \mathrm{mL}$

Table 5 Determine of antifungal activity by MIC method

\begin{tabular}{lcccccc}
\hline \multirow{2}{*}{ strains } & \multicolumn{5}{c}{ concentration of CW $(\mathrm{mg} / \mathrm{mL})$} \\
\cline { 2 - 6 } & 100 & 90 & 80 & 70 & 65 & 60 \\
\hline A. pullulans & + & + & - & - & - & - \\
G. virens & + & + & + & + & + & - \\
P. pinophilum & + & - & - & - & - & - \\
C. globosum & + & - & - & - & - & - \\
\hline
\end{tabular}

+: Mycelial growth inhibition of $100 \%$, - Less than $100 \%$ mycelial growth inhibition

\section{황련 열수 추출물의 항진균 효과}

생활 환경에서 존재하는 곰팡이에 대한 $\mathrm{CW}$ 의 항진균 효과는 다음의 방법으로 측정되었다. 각각의 곰팡이에 해당하는 배지를 만들어, $121{ }^{\circ} \mathrm{C}$ 에서 15 분 동안 멸균한 후 배지를 petri dish에 붓고, 배지가 굳은 후, 준비된 플러그를 배지의 중앙에 위치시 킨 후 황련 열수 추출물을 흡수시킨 paper disc를 접촉시켰다. 3-14일 동안 배양한 후, Table 1에 나타낸 균사생장 면적비율의 곰팡이 지수(Mold Index)를 평가한 결과 대조군으로 사용된 Hydmol-HDE는 5가지 유형의 곰팡이에 대해 항진균 효과를 확 인할 수 없었고, $\mathrm{CW}$ 는 A.niger를 제외한 4가지 유형의 곰팡이 에서 MI가 0으로 높은 항진균 효과를 나타냈다(Fig. 5).

\section{황련 열수 추출물의 최소저해농도(MIC) 측정}

항진균 활성을 보인 4종의 균주(Aureobasidium pullulans, Gliocladium virens, Penicilium pinophilum 및 Chaetomium globosum)에 대해 MIC를 측정한 결과 A. pullulans는 $90 \mathrm{mg}$ $\mathrm{mL}, G$ virens는 $65 \mathrm{mg} / \mathrm{mL}, P$. pinophilum 및 C. globosum은 $100 \mathrm{mg} / \mathrm{mL}$ 이었다(Table 5). MIC는 균주의 생장을 억제하는 가 장 낮은 농도로 결정하였으며, G. virens가 $65 \mathrm{mg} / \mathrm{mL}$ 로 $\mathrm{CW}$ 에 가장 민감하였다.

\section{황련 열수 추출물의 피부자극 측정}

패치테스트는 접촉할 물질의 감도를 결정하기 위해 따끔거림,

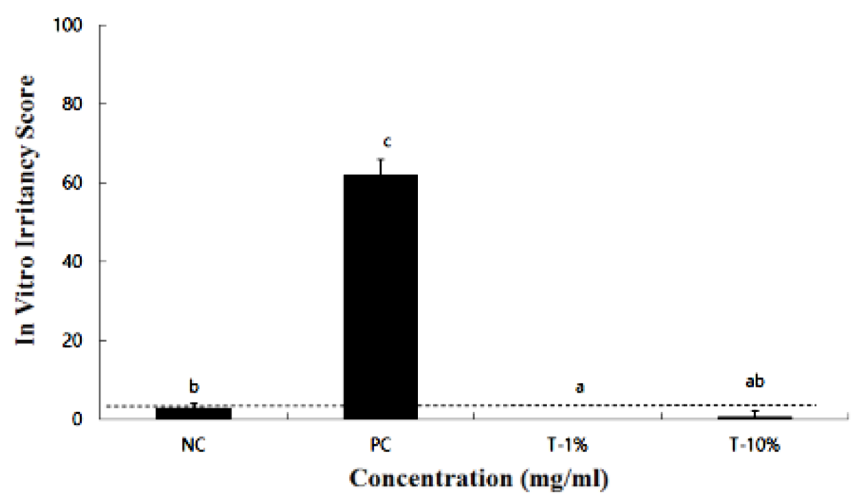

Fig. 6 The calculated IVIS values of CW in BCOP assay. values are mean \pm SD of 3 independent measurements. Values with different letters are significantly different $(p<0.005)$. NC: D.I water, PC: Ethanol, T-1\%: CW $10 \mathrm{mg} / \mathrm{mL}, \mathrm{T}-10 \%$ : CW $100 \mathrm{mg} / \mathrm{mL}$

가려움 및 발적의 반응으로 평가 되어진다. $10,50,100 \mathrm{mg} / \mathrm{mL}$ 의 농도로 $\mathrm{CW}$ 를 피부에 적용한 결과, $\mathrm{CW}$ 를 제거한 후 30 분 및 24시간 후에도 피부자극 반응은 관찰되어지지 않았다. 또한, 한국피부과학연구원(Seoul, Korea)에서 피부자극테스트를 실험 한 결과, 패치를 제거하고 24 및 48시간 후 각각 경미한 자극 이 관찰되었으나, ICDRG의 기준에 따라 자극은 받지 않은 것 으로 판단되었다(data not shown).

\section{동물대체시험법을 통한 황련 열수 추출물의 안자극 측정}

화장품이 제품으로 출시되기 위한 안전성 평가에서 화장품성분 의 무해함을 입증하기 위해 동물을 통한 독성 시험이 수행되어 왔다. 그러나, 최근 들어 동물의 복지에 대한 인식이 확산됨에 따라 동물실험에 대한 대안법이 권장되고 있으며, 동물대체시험 법의 한 종류인 BCOP 테스트는 심한 안자극에 대한 각막의 자 극정도를 측정하는 방법으로 알려져 있다. 본 연구에서는 $\mathrm{CW}$ 의 자극도를 확인하기 위해 $\mathrm{BCOP}$ 테스트의 방법에 따라 소의 각막에서 측정하였다. 에탄올을 양성대조군으로, D.I water를 음 
성대조군으로 사용하였고, 데이터의 결과값은 각막의 혼탁도와 투과도를 토대로 IVIS 값은 OECD테스트 가이드 라인437에 따 라 자극을 분류하는 기준으로 계산되었다. 실험 결과, 음성대조 군은 UN GHS 기준으로 IVIS가 3.0 이하로서 no category로 판정되었으며, 양성대조군은 62.1로 Category 1인 심한 안자극 물질로 판정되었다. $\mathrm{CW}$ 는 $10 \mathrm{mg} / \mathrm{mL}$ 에서 $-1.7,100 \mathrm{mg} / \mathrm{mL}$ 에 서 0.6으로(Fig. 6) $\mathrm{BCOP}$ 시험법에 근거하여 no category로 판 정되어 안자극에 안전한 물질임을 확인하였다.

\section{고 찰}

기능성 신소재의 탐색과 검증을 위한 연구가 이어져오고 있으 며 최근 합성 보존료가 첨가된 제품의 사용을 기피하게 되면서 안전성이 확보된 천연 항균성 물질을 이용하고자 하는 연구가 집중되고 있다[2]. 본 연구에서는 황련의 항균, 항진균의 활성 을 가지는 안전한 소재로서의 활용을 검토하기 위해 시료를 열 수 추출하여 실험을 수행하였다. 황련 열수추출물은 피부상재균 인 P. acnes, S. aureus, S. epidermidis에 대해 항균 효과를 보 였으며, 각기 다른 4곳에서 포집된 실내 낙하균(airborne microbe)에 대해서도 항균효과를 나타내었다. 황련의 항균지속 성을 분석한 결과, $100 \mathrm{mg} / \mathrm{mL}$ 농도에서 1 일 후까지는 항균 활 성이 관찰되지 않았으나, 7일 후 강한 항균 활성과 실험이 끝 나는 시점인 42 일까지 지속성이 관찰되었다. 황련 열수 추출물 은 $70,90,110,130,150$ 및 $180{ }^{\circ} \mathrm{C}$ 의 열처리 후에도 항균력 의 변화가 없는 열 안정성을 보여주었다. 이는 황련 열수 추출 물은 가공과정의 열처리에 안정하고, 지속성을 가지는 소재임을 보여준다. 황련 열수 추출물은 주변 환경에서 검출빈도가 높은 5 종의 곰팡이 중 4종에 대해 항진균 활성을 보였고, Gliocladium virens에 대해 강한 항진균 활성을 보였다. 이것은 동일 농도의 타 천연물에서는 나타나지 않는 항진균 활성을 보 여주는 주목할 만한 결과로, 높은 항진균 천연 소재로서의 화 장품 및 주거 환경을 안전하게 유지하는 재료로 응용가능성을 보여주었다. 황련의 패치테스트 결과 $\mathrm{ICDRG}$ 를 기준으로 자극 을 보이는 피실험자는 없었으며, BCOP assay를 이용한 ocular mucous membrane irritation evaluation test에서도 황련 열수 추출물은 OECD test guideline 437에 의거하여 자극을 보이지 않은 no category로 판정되었다. 이로 인해 황련 열수 추출물은 피부자극과 안자극을 보이지 않는 안전한 추출물로 간주된다. 상기 결과에 따라 황련 열수 추출물은 항균, 항진균 활성과 가 공시의 열 안정성 및 인체 안전성을 가지는 화장품 및 주거 환 경 산업의 소재 개발에 응용될 수 있음을 시사한다.

\section{초 록}

황련은 한의학에서 진정, 소염, 항균 및 해열에 쓰이고 있으며, 주 성분인 berberine은 강력한 항균작용을 가지는 것으로 알려져 있 다. 본 연구에서는 황련에 대한 피부상재균 및 주거환경의 실내 낙하균에 대한 항균효과와 주거 환경에서 검출빈도가 높은 곰팡 이에 대한 항진균 효과 및 인체에 대한 안전성을 조사하였다. 황 련 열수 추출물 $(\mathrm{CW})$ 은 Propionibacterium acnes, Staphylococcus aureus, Staphylococcus epidermidis에 대해 항균 효과를 보였으
며, 각기 다른 4곳에서 포집된 실내 낙하균에 대해서도 항균효 과를 보였다. $100 \mathrm{mg} / \mathrm{mL}$ 의 농도에서 42 일까지 항균의 지속력 과 열처리 후에도 항균력의 변화가 없는 열 안정성을 보여주었 다. $\mathrm{CW}$ 의 $\mathrm{MIC}$ 와 $\mathrm{MBC}$ 는 $S$. aureus는 $0.03,0.05 \mathrm{mg} / \mathrm{mL}, S$. epidermidis는 $0.50,0.75 \mathrm{mg} / \mathrm{mL}, P$. acne는 $0.10,0.15 \mathrm{mg} / \mathrm{mL}$ 였다. 주변 환경에서 검출빈도가 높은 5 종의 곰팡이 중 4 종에 대해 항진균 활성을 보였으며, 균사 생장의 $100 \%$ 를 억제할 수 있는 최저 농도로 결정하여 $\mathrm{MIC}$ 를 측정한 결과 Gliocladium virens 는 $65 \mathrm{mg} / \mathrm{mL}$ 이었다. Aureobasidium pullulans 에 대한 $\mathrm{MIC}$ 는 $90 \mathrm{mg} / \mathrm{mL}$, Penicilium pinophilum 및 Chaetomium globosum에 대한 MIC는 $100 \mathrm{mg} / \mathrm{mL}$ 로 측정되었다. 피부자극 테스트인 패치테스트와 안자극 테스트인 ocular mucous membrane irritation evaluation test에서도 $\mathrm{CW}$ 는 자극을 보이지 않는 안전한 추출물로 간주되었다. 따라서, 이러한 결과는, 황 련(Coptis chinensis)은 항균, 항진균 활성 및 인체 안전성을 가 지는 화장품 및 주거 환경 산업의 소재 개발에 응용될 수 있음 을 시사한다.

Keywords 대체 시험법 - 열안정성 - 피부상재균 - 항곰팡이 · BCOP assay

감사의 글 본 연구는 환경부에서 지원하는 2015 년 환경산업선진화기술개 발사업 (과제번호: 2015000150005)의 연구수행으로 진행되었습니다.

\section{References}

1. Tabance N, Kirimer N, Demirci F, Baser K (2001) Composotion and antimicrobial activity of the essential oils of Micromeria cristata subsp. phrygia and the enantiomeric distribution of borenol. J Agric Food Chem 49: 4300-4303

2. Sofos JN, Beuchat LR, Davidson PM, Johns EA (1998) Naturally ocurring and miscellaneous food antimicrobials. Regul Toxicol Pharmacol 28: 71-72

3. Conner DE, Beuchat IR (1984) Effest of essential oils from plants on growth of food spoilage yeasts. J Food Sci 49: 429

4. Woo WS (2001) Natural Product Chemistry Research Act. Seoul National University Press. 32-45

5. Oh DH, Ham SS, Park BK, Ahn C, Yu JY (1998) Antimicrobial activities of natural medicinal herbs on the food spoilage or food borne disease microorganisms. J Kor Food Sci Technol 30: 957-963

6. Cho MH, Bae EK, Ha SD, Park JY (2005) Application of natural antimicrobials to food industry. J Food Sci \& Industry 38: 36-45

7. Cho JY, Choi I, Hwang EK (2003) Antimicrobial acttivity of extracts from medicinal herbs against Escherichia coli. Kor J Vet Res 43: 625631

8. Kim HJ, Ahn MS, Kim GH, Kang MH (2006) Antioxidative from different aerial part. Kor J Food Sci Technol 38: 799-804

9. Yoon SY, Lee SY, Kim KBWR, Song EJ, Kim SJ, Lee SJ, Lee CJ, Ahn DH (2009) Antimicrobial activity of the solvent extract from different parts of Orostachys japonica., J Kor Soc Food Sci Nutr 38: 14-18

10. Eftekhar NS (1973) The Surgeon and Clean Air in the Operating room. Clinical Orthopacdics and Related Research 96: 188-194

11. Johnson MD, Kim HR, Chesler L, Taao-Wu G, Bouck N, Polverini PJ (1994) Inhibition of angiogenesis by tissue inhibitor of metalloproteinase. J Cell Physiol 160: 194-202

12. Robbins CA, Swenson L (2000) Health Effects of Mycotoxins in Indoor Air: A Critical Review. J Occup Environ Hyg 15: 773-784

13. Clark NM, Ammann HM, Brunekreef B, Eggleston P, Fisk WJ, Fullilove 
RE, Guernsey J, Nevalainen A, Von Essen SG, Brennan T, Douwes J (2004) Damp indoor spaces and health (executive summary), The National Academies Press Washington DC

14. Choi JT, Kim YS (1993) Investigation on Concentration of Airborne Microbes in a Hospital. Kor J Env Hlth Soc 19: 30-36

15. Chung YH, Hong JB, Chang YH (2001) Study on the microbial air pollution of urban living and indoor environment. Kor J Env Hlth Soc 27: $1-9$

16. Perez RI, Chacón J, Fidalgo A, Martin J, Paraiso V, Muñoz-Bellido JL (1997) Peritonitis by Aureobasidium pullulans in continuous ambulatory peritoneal dialysis. Nephrol Dial Transplant 12: 1544-1545

17. Bolignano G, Criseo G (2003) Disseminated Nosocomial Funga Infection by Aureobasidium pullulans var. melanigenum: a Case Report. J Clin Microbiol 41: 4483-4485

18. Miller JH, Giddens JE, Foster AA (1957) A survey of the fungi of forest and cultivated soils of Georgia. Mycologia 49: 779-808

19. Buommino E, Tirino V, De Filippis A, Silvestri F, Nicoletti R, Ciavatta ML, Pirozzi G, Tufano MA (2011) 3-O-methylfunicone, from Penicillium pinophilum, is a selective inhibitor of breast cancer stem cells. Cell Prolif 44: 401-409

20. Provost N, Shi C, She Y, Cyr T, Miller D (2013) Characterization of an antigenic chitosanase from the cellulolytic fungus Chaetomium globosum. Med Mycol 51: 290-299

21. Samson RA, Houbraken J, Summerbell RC, Flannigan B, Miller JD (2011) Common and important species of fungi and actinomycetes in indoor environments. Microogranisms in Home and Indoor Work Environments, pp 321-511

22. Ji YJ, Lee JW, Lee IS (2007) Antimicrobial effect of medicinal plants against methicllin-resistant Staphylococcus aureus(MRSA). J Life Sci 17: 412-419

23. Kim BS, Jang HS, Choi CS, Kim JS, Kwon GS, Kwun IS, Son KH, Sohn HY (2008) Antifungal activity of Zanthaxylum schinifolium against Fusarium graminearum, a barley powdery mildew fungus. J of Life Sci 18: 974-979

24. Mobley HLT, Cortesia MJ, Roseuthal LE, Jones BD (1988) Characterization of urease from Campylobacter pylori. J Clin Microbiol 26: $831-836$

25. Yun NR, Jeong IY, Lee YN, Lim JY (2008) Antibacterial activity of chitosan acetate on bacteria associated with food-borne disease. J Chitin Chitosan, 13: 30-35

26. Park KM, You JS, Lee HY, Baek NI, Hwang JK (2003) Kuwanon G: an antibacterial agent from the root bark of Morus alba against oral pathogens. J thnopharmacol 84: 181-185

27. National Committee for Clinical Laboratory Standards(NCCLS) (2002) Reference Method for Dilution Antimicrobial Susceptibility Tests for Bacteria That Grow Aerobically; Approved Standard M7-A6. NCCLS, Wayne

28. ASTM G-21 (2009) Standard Practice for Determining Resistance of Synthetic Polymeric Materials to Fungi, American Society for Testing and Material

29. Vinale F, Marra R, Scala F, Ghisalberti EL, Lorito M, Sivasithamparam K (2006) Major secondary metabolites produced by two commercial Trichoderma strains active against different phytopathogens. Lett Appl Microbiol 43: 143-148

30. Yamamoto A, Serizawa S, Ito M, Sato Y (1991) Stratum corneum lipid abnormalities in atopic dermatitis. Arch Derm Res 283: 219-223

31. Cazedey ECL, Carvalho FC, Fiorentino FAM, Gremião MPD, Salgado HRN (2009) Corrositex ${ }^{\circledR}$, BCOP and HET-CAM as alternative methods to animal experimentation. Braz J Pharm Sci 45: 759-766
32. Donahue DA, Kaufman LE, Avalos J, Simion FA, Cerven DR (2011) Survey of ocular irritation predictive capacity using Chorioallantoic Membrane Vascular Assay (CAMVA) and Bovine Corneal Opacity and Permeability (BCOP) test historical data for 319 personal care products over fourteen years. Toxicol In Vitro 25: 563-572

33. Kim SJ, Yang HY, Lee SG (2009) Antimicrobial Effect and Cytotoxicity of Chinensis Galla. Korean J Oriental Physiology \& Pathology 23: 412415

34. Mehnaz P, Md Abul H, Lim BO (2013) Antibacterial and antioxidant activities of Vaccinium corymbosum L. leaf extract. Asian Pac J Trop Dis 3: $444-453$

35. Kim YH, Lee SM, Cheon SJ, Jang MJ, Jun DH, Choi HJ, Cho WA, Lee JT (2007) Study on cosmeceutical activity of four kinds of Korea herb medicine materials. J Kor Soc F \& B 5: 130-138

36. Kim BC (2010) Quality Characteristics and medicated diet approach of Sulgidduk added with Gamcha(Hydranea serrata SERINGE) powder. Dissertation, Myong-ji University

37. Lee SG, Lee SH, Park EJ (2015) Antimicrobial and antioxidant activities of ethanol leaf extract of Dendropanax morbiferus Lev.. Korean J food cook sci 31: 515-523

38. Lee NK, Jung BS, Na DS, Yu HH, Kim JS, Paik HD (2016) The impact of antimicrobial effect of chestnut inner shell extracts against Campylobacter jejuni in chicken meat. Food Sci Technol 65: 746-750

39. Jang MJ, Kim YH, An BJ, Lee CE, Lee JT, Kim SH, Lee BG, Lee DH (2008) Study on anti-inflammatory and anti-microbial effect of Pinus rigida Mill. Inner bark extracts as a cosmetic material. J Korean For Soc 97: $215-220$

40. Han SH (2011) Antimicrobial effects of edible medicinal herbs extracts on foodborne pathogens. Dissertation, Sunchon National University

41. Park HS (2011) Cultivation of Mushroom(phellinus linteus Mycelium) on Brown Rice Investigation of antibacterial activity. Dissertation, Kyonggi University

42. Yun JJ (2016) Antibacterial and antioxidant activities of ethanol extracts and fractions from Curcuma longa Linne. Dissertation, Sunchon National University

43. Hong SB, Lee CH (2015) Antimicrobial activity of Houttuynia cordata ethanol extract against major clinical resistant microorganisms. Korean J Clin Lab Sci 47: 140-146

44. Oh YO (2016) A study of anti-oxidative, anti-melanogenic, antimicrobial from teatree(Melaleuca alternifolia) extract under water, ethanol extract condition. Dissertation, Daegu Haany University

45. Lee SJ (1999) Isolation and identification of antimicrobial active substance from Coptis chinesis Franch extract. Dissertation, Kyung Sang University

46. Kim HJ (2010) Antimicrobial activity and bactericidial potency of Galla rhois extracts. Dissertation, Keimyung University

47. Cox CS (1989) Airborne bacteria and viruses. Sci Prog 73: 469-499

48. Park HS, Kang IS, Kim JW, Eo HJ (2004) A study of airborne microbes in the NSICU according to number of persons who pass through every hour. J Kor Acad Funda Nurs 11: 41-48

49. Chung KH, Kim JT, Lee SH, Lee YC (2001) Antmicrobial activity of omija(Schizandra chinensis) extracts. J Kor Soc Food Sci Nutr 30: 127132

50. Lee SY, Ahn DH, Hong YK, Kim KBWR, Kim SJ, Lee SJ, Lim SM, Song EJ, Yoon SY (2009) Antimicrobial activity of ethanol extract from Sargassum thunbergii. J Kor Soc Food Sci Nutr 38: 502-508

51. Lee CE, Jo JK, Kim JD, Lee DG, Kim WS, Lee SH (2017) Verification of antibacterial activities of oriental herbal medicine extracts. J Life Sci 27: $611-616$ 